\title{
Older Consumers in Malaysia
}

\author{
BY FON SIM ONG ${ }^{1} \mathcal{E}$ DAVID R. PHILLIPS 2
}

\begin{abstract}
The main objective of this study was to understand the concerns and problems faced by older people in an industrializing middle-income country, Malaysia, in their process of acquiring products to meet their everyday needs. Respondents aged 55 and over were interviewed in eight states throughout Peninsular Malaysia providing 1356 usable questionnaires; two-thirds from urban and one-third from rural areas. Education, health status, and life satisfaction were recorded. Service patronage behaviour was examined for four main categories of commonly-sought consumer goods: groceries, health supplements, apparel, eating outlets, plus selected services (public transport, vacation packages and financial services). The findings showed that older adults in Malaysia are rather discerning consumers. Many respondents are price conscious and have developed consumer attitudes with regard to attitude of staff and assistance rendered. Many display a good ability to discriminate and to select, especially on the basis of price and durability of products and many appear to be acting as effectively as consumers in any other age group.
\end{abstract}

Keywords: Malaysia, older persons, older consumers, consumer behaviour, successful, ageing.

1 Fon Sim Ong, Faculty of Business and Accountancy, University of Malaya, Kuala Lumpur, Malaysia.

2 David R. Phillips, Asia-Pacific Institute of Ageing Studies, Lingnan University, Tuen Mun, Hong Kong 


\section{Introduction}

Malaysia's population of approximately 25 million people is not currently particularly elderly although this will change over the next two decades or so and Malaysia will certainly be an ageing society by 2040 (Ong 2002; ESCAP 2006). The 2000 Census indicated that 6.2 per cent, 1.452 million people, were aged 60 or over and estimates for 2004 put this at 6.5 per cent (around 1.67 million people) (Department of Statistics 2001) and ESCAP (2006) puts this at 7 per cent. By 2020, 9.5 per cent of the country's population is likely to be aged 60 years and over. Malaysia has adopted United Nations guidelines and uses the age of 60 and over in formulating and implementing plans for its senior citizens. However, the present common retirement age of 56 seems to suggest that the threshold for ageing is felt to begin at a somewhat earlier age.

Like many other Asia-Pacific countries, Malaysia has been experiencing improved health, longer life expectancy, low mortality and concomitant declining fertility (Phillips 2000; ESCAP 2006). Life expectancy at birth (LEB) was given as 71 for males and 76 for females in 2003, up from 69.4 and 74.1 in the mid-1990s, and very much improved from the 1950s when life expectancy was only around 55 years for men and 58 years for women. Total fertility rates in 2003 were about 2.9 children per woman of childbearing age (2.7 in 2006), considerably down from previous levels. As in most countries of the region, the combination of all of these features has brought about a change in the demographic profile of the country's population (Phillips 2000; ESCAP 2002a). Over the past four censuses (1970, 1980, $1991 \& 2000)$, the proportion of younger age groups (15 years and below) has been decreasing, while the proportion of older population has been on the rise. The proportion of elderly people will grow from $6.3 \%$ in 2000 to $12.0 \%$ in 2030 , doubling in proportion but by three times or more in absolute numbers. At the 2000 Census, $7.6 \%$ of Chinese Malaysians were aged $60+$, whilst $5.6 \%$ of Indians and Malays were in this age group. Projections for 2020 put Chinese then aged $60+$ at $14.4 \%$, Indians at $10.4 \%$ and Malays at $7.9 \%$.

According to the Population and Housing Census of Malaysia, 2000 (Pala 2005), 22.8\% of the population aged 60 years or older were employed 
compared to $23.9 \%$ in 1991 . In the context of Eastern and Asian culture, as we discuss below, children are often regarded as the safety net for old age and financial support from children is taken as a norm, whether it is realistic or not. In turn, older people often reciprocate by looking after grandchildren or providing other types of assistance such as housekeeping. Malaysia's Censuses of 1991 and 2000 show the trend towards increasing participation by older persons in the service sector, especially the retail industry, whereas participation in the agriculture sector shows a decline.

\section{Older Persons as Consumers: A Growing (Yet Neglected) Market in Malaysia}

Looking forward, by 2020, Malaysia will be a fairly mature society demographically. Admittedly, the rate of demographic ageing of Malaysia's population is slower than that of many regional neighbors such as China, Singapore, Thailand and Hong Kong. However, the increase in the proportion of older persons will make it very inadvisable for the government and private sector to ignore the social and economic impacts of population ageing and especially the needs of older people as consumers.

The increasingly larger proportion of older adults makes it difficult for marketers, too, to ignore the segment's attractiveness. Business opportunities are abundant provided marketers understand the needs and wants of older people so that firms can then develop marketing programmes that better appeal to this segment of the market. Internationally, older shoppers are a market segment that should be nurtured (Moschis et al. 2004). They increasingly have growing purchasing power in many high and middle-income countries, drawn often from pensions, investments and property and they are sometimes almost the only growing consumer segment, referred to occasionally as the 'silver market'. Not only may older consumers be different from the younger age groups, they are also heterogeneous as consumers among themselves (Silvers 1997; Dychtwald 1997). They are also substantial consumers, a point sometimes previously overlooked: in the United States, for example, the over-55 market segment purchased $30 \%$ of all food consumed in the home and older consumers may tend to stay more loyal (Moschis et al. 2004). As 
the proportion of the population born in the baby-boomer years of 19461964 advances into the older age groups over the next decade or so, their changing needs are likely to become economically important for marketers. It was against this broad background internationally and locally that the current research was undertaken.

\section{Older Asian Consumers: Invisible Consumers or With A Consumer Identity?}

Older persons in many Asian cultures appear to be thought of by both public and private sectors as "invisible consumers". Their consumption needs and choices are often taken for granted and assumed to be catered for by their family members under traditional Asian family value norms (Phillips 2000). Whilst the purchasing power and consumer rights of older groups have been widely recognized and catered for in the West, this is rarely so in middle income countries and even less so in low income countries. Within the Asia-Pacific region, the importance and power of the 'silver market' is increasingly recognized in some of the maturing economies such as Japan and is of growing importance in Taiwan, Korea, Hong Kong and Singapore. However, elsewhere, older persons as a productively ageing group, and especially as a sub-group of the population with growing purchasing power, are still either ignored or thought of as small and insignificant. Ironically, certain aspects of Asian culture, especially filial piety ( $\mathrm{Ng}$ et al. 2002) and a tendency to regard older persons with venerable respect rather than as active participants, may have actually contributed to this neglect of the 'silver market' and older persons as consumers. Indeed, there tends to be a predilection to regard older persons as vulnerable, often as supplicants, welfare-oriented and in need of social protection and assistance (ESCAP 2001, 2002a,b), rather than as an important consumer group with growing needs and - especially - purchasing clout.

In a wider context, there is evidence that consumption and the ability to consume and exercise choice have important effects on identity in later life (Gilleard 1996). Kontos's (2005) remarks below are relevant, as are observations by Blaikie (2005) about the importance of having control over, say, how and where time is spent, a key aspect of leisure and 
implicitly of consumerism. We feel that some older consumers may care to share a common identity through similar consumption patterns; others may be more of the liberationist perspective that Blaikie refers to, wishing to experiment with new ways of living. Whether this has as much impact in more traditional ageing societies such as is usually assumed of countries such as Malaysia will be a fascinating area of ongoing investigation.

Today, however, as Lloyd-Sherlock (2004) notes, debates about ageing are often infiltrated with what he calls the negative paradigms of ageing associated with dependency, vulnerability and an inherent lack of capability. Positive aspects of consumerism and choice are rarely part of the ageing paradigm. Kontos $(2005$, p.33) sums up a complementary view succinctly and her observations could well be applied to modern-day Malaysia and many other countries of the region. She suggests that a spirit of an 'information society', a 'postindustrial society' and a 'postmodern culture' combine in an emergent consumer culture discourse that 'elderhood has been reconstructed as a marketable lifestyle that connects the commodified values of youth with various body care products and techniques that mask the appearance of age'. Within the consumer culture, the older body is still nevertheless rejected as a possible site of beauty - presumably this would not fit in with the negative paradigm.

Yet it is evident that this negative paradigm is increasingly being reacted against in the West. Consumer-oriented publications, for example, in the United Kingdom by Saga, numerous sources in the USA and Canada and in Australia (for example, 50-Something of the National Seniors Association) at least go some way towards countering this mindset. However, we feel that the proliferation of implicitly negative images of old age in global consumer culture may have implicitly relegated older persons in more traditional societies to a less-than-consumer position. This current study in Malaysia, as an ageing and growingly affluent society, as well as a key regional economy, address some aspects of this conundrum and provides an initial view of older consumers' perspectives. In fact, we argue that it is imperative to understand how older consumers behave in the marketplace of middle-income countries as elsewhere they have been found to be somewhat different from younger 
consumers (Burt \& Gabbott 1995; Hooyman \& Kiyak 2005; Lumpkin et al. 1985; Novak 2006).

The study therefore attempts to draw preliminary implications for future service delivery and marketing strategies from a study of current consumer experience. It connects with successful and active ageing concepts in which older persons should be full participants in society as equal partners experiencing only the same levels of discrimination as all age groups and not as older consumers (Rowe \& Kahn 1997; WHO 2002; Kinsella \& Phillips 2005; Andrews \& Phillips 2005). Notably, freedom from discrimination is the first of the six strategies outlined in the Policy Action Plan for the Elderly, Malaysia 1999, so it is valuable to test whether older consumers in the country actually feel they can express their consumer rights.

\section{Purpose and Aims of The Study}

The aims of the study were:

- To investigate patronage behaviour of older adults for four categories of commonly consumed products (groceries, health supplements, apparel, eating outlets) and services (transport, vacations and financial services)

- To understand the concerns and perceived problems faced by older adults in the process of acquiring such products and services to meet their everyday needs

- From these, to suggest future strategies and directions for delivery of consumer products and services bearing in mind the older segments of the population

\section{Research Design and Methods}

An empirical research design using face-to-face interviews with 1,500 respondents aged 55 and above from 8 states in Peninsular Malaysia was chosen. Because of the nature of the questionnaire, potential respondents with evident cognitive problems were excluded, as were those who were housebound or bed-bound. This therefore inevitably skews the respondents towards the more healthy and active members of the older popula- 
tion and the findings should be interpreted accordingly. Just under twothirds of respondents were from urban areas and approximately onethird from rural areas of peninsular Malaysia (the East Malaysian states of Sabah and Sarawak on the island of Borneo were not included in the current analysis but will be available in later analyses). This proportion reflects the actual distribution of population in Malaysia which is approximately $62 \%$ urban. Training sessions were conducted for the interviewers and house-to-house interviews were conducted in the appropriate local languages, mainly English, Bahasa Malaysia (the national language) and Chinese.

The questionnaire was comprehensive concerning service usage, attitudes and satisfaction. This article reports only selected findings from the comprehensive sections which covered purchase patterns and behaviour for:

- Goods and products

- Services

- Satisfaction with shopping facilities

- Life satisfaction

- Demographic profile

\section{The Survey and Analysis}

The survey was conducted during the months of May to September, 2004. The target respondents were 200 in Kuala Lumpur/Petaling Jaya, 200 each in Kuantan, Penang, Johor Bahru and Kota Bahru, 150 each in Malacca and Ipoh and 100 each in Alor Setar and Kuala Terengganu (Map 1). Non-probability sampling using a quota sampling method was adopted. Care was taken to ensure that respondents were drawn according to criteria: $60 \%$ were urban and $40 \%$ rural dwellers; males and females numbered $50 \%$ each and the different ethnic groups were represented Malays: $60 \%$, Chinese: $30 \%$, Indians: $10 \%$. Of the 1,500 questionnaire administered, 1,356 were ultimately suitable for analysis $(90.4 \%)$, others were omitted due to incomplete or unclear answers. Four to five trained interviewers operated per location and questionnaires were checked daily. 
Map 1. Percentage of respondents by location, Peninsular Malaysia.

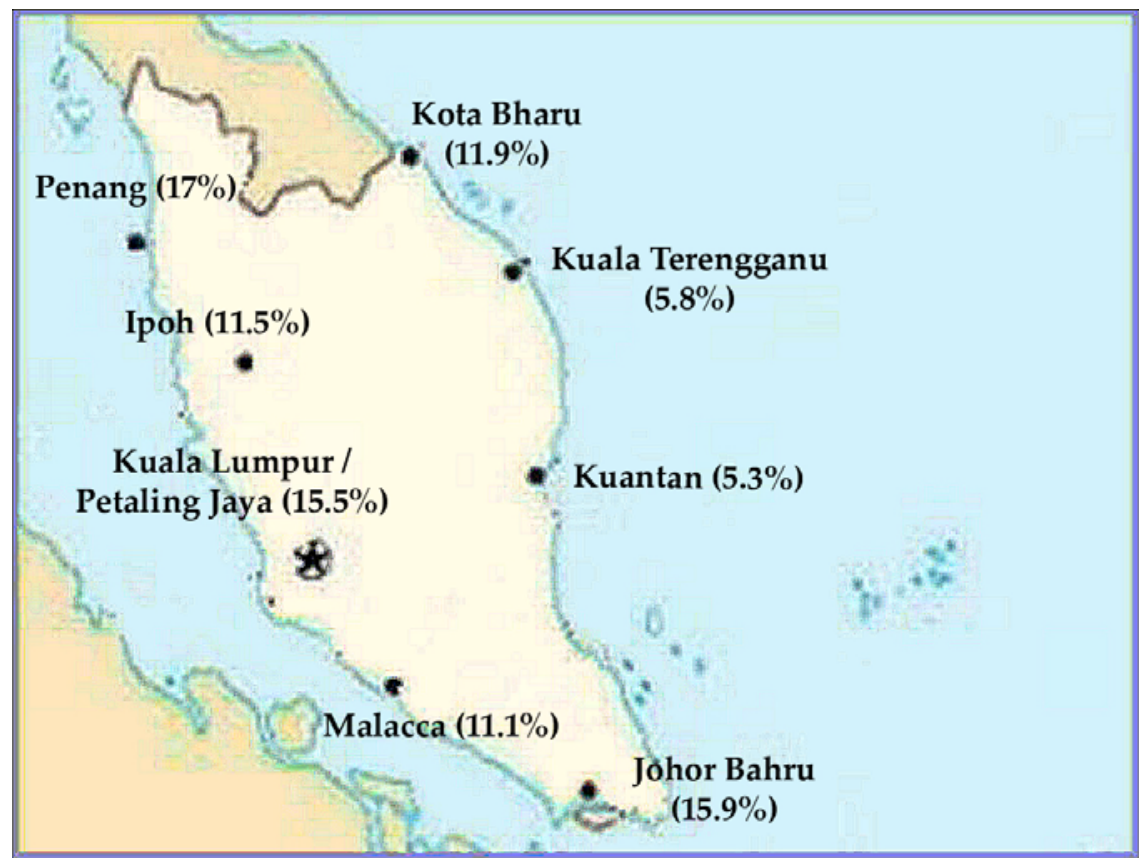

\section{Demographic Profile}

In terms of age, $36.6 \%$ of the final sample (1,356 respondents) were aged 55 to 59 years old (298 males and 198 females), about $43 \%$ were in their sixties (325 males and 252 females) and the remainder (283 or 20.9\%) were aged 70 years old and above (154 males and 129 females). Of this the oldold age groups (75 years and older) made up $10.5 \%$. Of the final analysed group, $57 \%$ (777 out of 1,356) were males, a slight over- representation in terms of the initial target. However, in practice, this might be expected as a large proportion of families in Malaysia still observe the cultural expectation that males should deal with external affairs. Only $6.5 \%$ of respondents had tertiary or professional qualifications, and $15.9 \%$ had received no formal education. As the largest ethnic group in this country, the Malays made up about $56 \%$ of the sample while the Chinese and In- 
dians formed $29.4 \%$ and $11.2 \%$ of the sample. In terms of religion, about 57\% were Muslim, 24\% Buddhist, 10\% Christians and 8\% Hindu.

Economically, the monthly income of about $32 \%$ of the respondents was RM 1,000 or less (RM $3.8=$ US\$ 1 ). Almost $51 \%$ had a monthly household income between RM 1,000 and RM 3,000 and about 17\% of RM3,001 and above. In terms of employment status, more than half were retired or unemployed (58\%), $200(14.7 \%)$ were in full-time employment, $60(4.4 \%)$ were retired but worked full-time, $192(14.2 \%)$ retirees worked part-time, and $8.7 \%$ were employed on a part-time basis. In short, about $42 \%$ were employed either part-time or full-time. Slightly more than three-quarters of respondents were married with children while $16 \%$ were widowed. The majority of the respondents with children (53\%) had four children or fewer although $11 \%$ had eight or more children. In terms of living arrangements, $37.9 \%$ were living with a spouse and unmarried children, $20.7 \%$ lived with a spouse and married children. $18.1 \%$ lived with their spouse only and $15.7 \%$ lived with children only. Only $6 \%$ of respondents lived alone while about $1 \%$ lived with parents. In other words, older people who lived alone and those who lived with a spouse only could be classified as active consumers who made purchase decisions about household products as they are the decision makers and purchasers. Those living with unmarried children could also be playing a role as decision makers in line with the Asian culture that emphasises respect for the elderly. In the context of Malaysia, the roles of unmarried children are usually seen as that of an influencer or information gatherer.

\section{Purchasing Patterns and Behaviour}

The older consumers in this study spent a monthly average of RM 463.37 on food (Table 1), which is about 9\% higher than the average RM 426 spent by Malaysian households headed by a person between 45 and 64 years old based on the report of Household Expenditure Survey Malaysia, 1998/99. Average household expenditure of respondents were also higher for beverages and tobacco (RM 69.80); medical care and health expenses (RM 96.90); food away from home (RM 121), and beverages away from home (RM 28.10); when compared to households headed by a person age between 45 and 64 years. 
International Journal of Ageing and Later Life

Table 1. Mean Monthly household expenditure pattern on products and services.

\begin{tabular}{|c|c|c|c|c|c|c|}
\hline \multirow[b]{2}{*}{ Items } & \multicolumn{2}{|c|}{ Gender } & \multicolumn{3}{|c|}{ Age Groups } & \multirow[b]{2}{*}{ Total } \\
\hline & Male & Female & $\begin{array}{l}55-64 \\
\text { years }\end{array}$ & $\begin{array}{l}65-74 \\
\text { years } \\
\end{array}$ & $\begin{array}{l}75 \text { years } \\
\& \text { above }\end{array}$ & \\
\hline Food & 461.02 & 466.51 & 485.50 & 445.54 & $384.90^{* *}$ & 463.40 \\
\hline $\begin{array}{l}\text { Gross rent, fuel and } \\
\text { power }\end{array}$ & 155.42 & 170.52 & 172.31 & 151.81 & $129.31^{* *}$ & 161.90 \\
\hline $\begin{array}{l}\text { Transport and } \\
\text { communication }\end{array}$ & 141.28 & $124.62^{* *}$ & 142.30 & 125.53 & $111.01^{* *}$ & 134.20 \\
\hline $\begin{array}{l}\text { Expenditure on food } \\
\text { away from home }\end{array}$ & 130.72 & $107.92^{* *}$ & 120.41 & 118.98 & 129.78 & 121.00 \\
\hline $\begin{array}{l}\text { Medical care and } \\
\text { health expenses }\end{array}$ & 88.53 & $108.13^{* *}$ & 95.21 & 106.24 & $81.08^{*}$ & 96.90 \\
\hline $\begin{array}{l}\text { Recreation, enter- } \\
\text { tainment, education } \\
\text { and cultural services }\end{array}$ & 86.38 & 90.21 & 103.75 & 64.75 & $61.89^{* *}$ & 88.00 \\
\hline $\begin{array}{l}\text { Beverages and } \\
\text { tobacco }\end{array}$ & 74.29 & 63.84 & 70.64 & 72.98 & 56.50 & 69.80 \\
\hline $\begin{array}{l}\text { Other miscellaneous } \\
\text { goods \& services }\end{array}$ & 56.20 & 53.28 & 58.85 & 49.11 & 48.48 & 55.00 \\
\hline Clothing and footwear & 49.23 & 46.83 & 54.10 & 41.51 & $32.66^{* *}$ & 48.20 \\
\hline $\begin{array}{l}\text { Furniture, furnishings } \\
\& \text { household equip- } \\
\text { ment \& operations }\end{array}$ & 36.36 & 35.10 & 37.66 & 33.06 & 31.71 & 35.70 \\
\hline $\begin{array}{l}\text { Expenditure on bev- } \\
\text { erages away from } \\
\text { home }\end{array}$ & 31.19 & $23.85^{* *}$ & 29.58 & 23.31 & 32.37 & 28.10 \\
\hline TOTAL & 1310.42 & 1290.83 & 1370.33 & 1232.82 & $1098.88^{* *}$ & 1302.20 \\
\hline
\end{tabular}

${ }^{*}$ significance at $5 \%, * *$ Significance at $1 \%$.

Significance tested using One-way ANOVA for the three age groups and t-test for gender comparison. 
Table 1a. Average monthly expenditure per household by gender and age of head of household, Malaysia, 2004/05 (RM).

\begin{tabular}{|c|c|c|c|c|}
\hline \multirow[t]{2}{*}{ Items } & \multicolumn{2}{|c|}{$\begin{array}{c}\text { Gender of Head of } \\
\text { Household }\end{array}$} & \multicolumn{2}{|c|}{$\begin{array}{c}\text { Age of Head of } \\
\text { Household (years) }\end{array}$} \\
\hline & Male & Female & $45-64$ & 65 and above \\
\hline Food & 405 & 326 & 435 & 385 \\
\hline $\begin{array}{l}\text { Gross rent, fuel and } \\
\text { power }\end{array}$ & 438 & 385 & 450 & 409 \\
\hline $\begin{array}{l}\text { Transport and com- } \\
\text { munication }\end{array}$ & 437 & 303 & 449 & 308 \\
\hline $\begin{array}{l}\text { Expenditure on food } \\
\text { away from home }\end{array}$ & 174 & 139 & 174 & 118 \\
\hline $\begin{array}{l}\text { Medical care and } \\
\text { health expenses }\end{array}$ & 28 & 25 & 31 & 37 \\
\hline $\begin{array}{l}\text { Recreation, enter- } \\
\text { tainment, education } \\
\text { and cultural services }\end{array}$ & 137 & 91 & 144 & 85 \\
\hline $\begin{array}{l}\text { Beverages and } \\
\text { tobacco }\end{array}$ & 38 & 18 & 36 & 24 \\
\hline $\begin{array}{l}\text { Other miscellaneous } \\
\text { goods \& services }\end{array}$ & 168 & 158 & 186 & 134 \\
\hline $\begin{array}{l}\text { Clothing and foot- } \\
\text { wear }\end{array}$ & 61 & 47 & 62 & 41 \\
\hline $\begin{array}{l}\text { Furniture, furnish- } \\
\text { ings \& household } \\
\text { equipment \& opera- } \\
\text { tions }\end{array}$ & 87 & 61 & 31 & 37 \\
\hline $\begin{array}{l}\text { Expenditure on bev- } \\
\text { erages away from } \\
\text { home }\end{array}$ & 37 & 27 & 36 & 24 \\
\hline TOTAL & 2010 & 1580 & 2034 & 1602 \\
\hline
\end{tabular}

Source: Report on Household Expenditure Survey 2004/05, Department of Statistics, Malaysia, p.62 and p.68. 
For the purpose of analysis, these 1,356 respondents were reclassified into three older age groups: 55-64 ( $\mathrm{N}=822,60.6 \%), 65-74(\mathrm{~N}=391,28.8 \%)$ and 75 and older $(\mathrm{N}=143,10.6 \%)$. Analysing the three age groups in Table 1 with respect to total monthly household expenditures, the younger age group tended to spend more compared to the older age groups $(F=9.11$, $p<.001)$. The younger age group (55-64) had a significantly higher level of total monthly expenditure compared to those in the age groups of 6574 and 75 and older (at $p<.020$, and $p<.001$, respectively). However, males did not differ from females with respect to monthly household expenditure. The younger age group tended to spend more on food $(F=$ 7.130, $p<$. 001), gross rent, fuel and power $(F=4.752, p<.009)$, transport and communication $(F=5.435, p<.004)$, clothing and footwear $(F=6.692$, $p<.001)$, as well as on recreation, entertainment and education $(F=4.476$, $p<.012)$ whereas the older age groups spent marginally more on medication and health care $(F=3.050, p<.048)$, for which the 65-74 age group spent marginally more than the 75 and older age group (at $p<.061)$ while there was no significant difference with the 55-59 age group. For expenditure on food, and clothing and footwear, the age group of 55-64 spent significantly more than the 75 and older group (at $p<.002$ and $p<.010$, respectively). Expenditure on footwear and clothing for the younger age group of 55-64 also differed significantly from the age group 65-74 (at $p$ $<.031$ ). For transport and communication, the age group of 55-64 spent significantly more than the 75 and older group (at $p<.018$ ).

Males did not differ significantly from females with respect to their household expenses except for transport and communications $(p<.013)$, food and beverages away from home $(p<.002)$, and medical expenses $(p$ $<$.001). Males tended to spend more on transport and communications and food and beverages away from home while females spent more on medical bills. The expenditure patterns of males and females are consistent with what might be expected of the typical pattern in which males who are the major bread winners and are expected to spend more on food and beverages away from home, and on transport and communications.

A comparison of household expenditure patterns of households headed by someone aged 45-64 with those of households headed by persons aged 65 and above in the Report of Household Expenditure Survey 
2004/05 (Government of Malaysia) shows that the average monthly expenditure of older respondents was lower compared to the average monthly expenditure of 45-64 headed households (Table 1a). Breakdown by categories of expenditure in the Report of Household Expenditure Survey shows that in 2004/05, older adults (65 years and above) were spending more on gross rent, fuel and power as well as on transport and communications compared to the amount spent by respondents in the present study due perhaps to the increase in fuel prices experienced by Malaysians in 2005. The Household Expenditure Survey also shows a lower amount spent on medical care and health expenses compared to research results of the present study. This does not necessarily indicate improved health status but perhaps is indicative of a switch to government clinics which are less expensive instead of private health care facilities.

\section{Purchasing Patterns and Behaviour for Various Products}

The survey covered the following aspects of older respondents' consumer attitudes and behaviour with respect to four main categories of products - groceries, apparel, health supplements and eating-out:

- Preferred patronage outlets and reasons for preferences

- Frequency of purchases

- Preferred time of purchases

- Time spent on purchasing products

- Shopping companion(s)

- Preferred mode of product delivery

A preliminary analysis with respondents showed the factor considered most important that influenced purchase decision-making was durability (Mean=4.39, SD=0.79) followed closely by quality (Mean=4.34, SD=0.84) and safety features (Mean=4.33, $\mathrm{SD}=0.83$ ). Comfort $(\mathrm{Mean}=4.30, \mathrm{SD}=0.78$ ) and price (Mean $=4.30, \mathrm{SD}=0.82$ ) were also ranked high in importance whereas design (Mean=2.80, $\mathrm{SD}=1.34$ ) and brand $(M e a n=2.68, \mathrm{SD}=1.40)$ 
International Journal of Ageing and Later Life

Table 2. Attributes important in purchase decision-making.

\begin{tabular}{|c|c|c|c|c|c|c|}
\hline \multirow[b]{2}{*}{ Items } & \multicolumn{2}{|c|}{ Gender* } & \multicolumn{3}{|c|}{ Age Groups* } & \multirow{2}{*}{$\begin{array}{l}\text { Total } \\
\text { Mean } \\
\text { (SD) }\end{array}$} \\
\hline & Male & Female & $\begin{array}{l}55-64 \\
\text { years }\end{array}$ & $\begin{array}{l}65-74 \\
\text { years }\end{array}$ & $\begin{array}{c}75 \text { years \& } \\
\text { above }\end{array}$ & \\
\hline Durability & 4.42 & 4.34 & 4.43 & 4.36 & $4.17^{* *}$ & $\begin{array}{c}4.39 \\
(0.79)\end{array}$ \\
\hline Quality & 4.39 & $4.28^{* *}$ & 4.38 & 4.35 & $4.12^{* *}$ & $\begin{array}{c}4.34 \\
(0.84)\end{array}$ \\
\hline Safety features & 4.39 & $4.26^{* *}$ & 4.36 & 4.32 & 4.23 & $\begin{array}{c}4.33 \\
(0.83)\end{array}$ \\
\hline Comfort & 4.34 & $4.25^{*}$ & 4.33 & 4.30 & $4.13^{*}$ & $\begin{array}{c}4.30 \\
(0.78)\end{array}$ \\
\hline Price & 4.33 & 4.22 & 4.29 & 4.30 & 4.12 & $\begin{array}{c}4.30 \\
(0.82)\end{array}$ \\
\hline $\begin{array}{l}\text { User-friendli- } \\
\text { ness }\end{array}$ & 4.15 & $4.05^{*}$ & 4.11 & 4.12 & 4.07 & $\begin{array}{c}4.11 \\
(0.89)\end{array}$ \\
\hline Clear label & 3.74 & 3.64 & 3.73 & 3.72 & $3.44^{*}$ & $\begin{array}{c}3.70 \\
(1.36)\end{array}$ \\
\hline $\begin{array}{l}\text { After-sales } \\
\text { service }\end{array}$ & 3.48 & $3.31^{* *}$ & 3.48 & 3.38 & $3.02^{* *}$ & $\begin{array}{c}3.41 \\
(1.23)\end{array}$ \\
\hline $\begin{array}{l}\text { Environmentally } \\
\text { friendly }\end{array}$ & 3.33 & 3.28 & 3.36 & 3.32 & $2.99^{* *}$ & $\begin{array}{c}3.31 \\
(1.23)\end{array}$ \\
\hline Design & 2.72 & $2.91^{*}$ & 2.82 & 2.77 & 2.82 & $\begin{array}{c}2.80 \\
(1.34)\end{array}$ \\
\hline Brand & 2.72 & 2.63 & 2.73 & 2.61 & 2.63 & $\begin{array}{c}2.68 \\
(1.40)\end{array}$ \\
\hline
\end{tabular}

Mean is calculated based on a 5-point-scale, from 1 (not important at all) to 5 (very important).

*significance at $5 \%,{ }^{* *}$ Significance at $1 \%$.

Significance tested using One-way ANOVA for the three age groups and t-test for gender comparison.

were not important (Table 2). A key feature was that men differed significantly from women in the factors considered important in six of the 12 factors surveyed: quality $(p<.012)$, safety features $(p<.004)$, comfort $(p$ $<.030)$, user friendliness $(p<.040)$, after sales service $(p<.010)$ and design $(p$ 
$<.010)$. For all these attributes, males rated a higher degree of importance compared to females except for design to which females attached a higher level of importance. In order to examine whether the differences were due to the effect of age or gender, 2X2 ANOVA was conducted. Results showed the gender effect was supported for safety features $(p$ $<.001)$ and design $(p<.043)$ while quality was due to both age $(p<.011)$ and gender $(p<.001)$. The difference in environmental friendliness $(p<.018)$ was due to the age effect.

ANOVA tests showed that the younger age group differed significantly from the older age groups with respect to six of the 12 factors: durability $(F=6.76, p<.001)$, quality $(F=5.84, p<.003)$, comfort $(F=4.17, p$ $<.016)$, clear labels $(F=3.29, p<.038)$, after-sales service $(F=8.85, p<.001)$, and environmental friendliness $(F=5.71, p<.003)$, in which the former placed more importance compared to the latter. Again, the findings are not surprising as the younger age groups could possibly be more educated and hence had higher level of awareness toward the environment and the importance of having clear labels. Tests for differences between the age groups showed that the age group of 55-64 differed significantly from those in the age group of 75 and older at $p<.001$ for durability and after sales service, quality $(p<.019)$, environmental friendliness $(p<.003)$ and comfort $(p<.016)$. In addition, the age group 65-74 also differed significantly from those aged 75 and older on four of the characteristics: durability $(p<.049)$, after sales service $(p<.010)$, quality $(p<.019)$, and environmental friendliness $(p<.022)$.

\section{Purchase Behaviour for Selected Products}

In this study, older adults were asked to indicate up to a maximum of three types of stores that they patronized for groceries, health supplements, clothing, and eating outlets. ${ }^{1}$

For grocery needs, sundry shops (or provision shops) were the most popular among older adults since $782(57.7 \%)$ respondents reported preference for it due probably to their accessibility and convenience as these

1 (Additional tables are available online at http://www.ep.liu.se/ijal/v2/i1/ a5/ijal07v2i1a5_supplements.pdf). 
shops are found in all residential areas. The next most preferred place to shop for groceries was the wet market ( $\mathrm{N}=499,36.8 \%)$ which could be attributable to the availability of both wet and dry foods as well as their traditional Asian ambience and supermarkets were the third $(\mathrm{N}=460$, $33.9 \%)$. A larger number of those aged 55-64 years old had a preference for sundry shops $(\mathrm{N}=460,60.0 \%)$ followed by supermarkets $(\mathrm{N}=324$, $39.4 \%)$, and wet markets $(\mathrm{N}=285,34.7 \%)$. For the 65-74 group, the preference was sundry shops $(\mathrm{N}=228,58.3 \%)$, wet markets $(\mathrm{N}=157,40.2 \%)$ and supermarkets $(\mathrm{N}=103,26.3 \%)$. For the 75 and older age group, sundry shops were favoured by 94 respondents $(65.7 \%)$ of them followed by wet markets which were preferred by 57 (39.9\%) of them. Sundry shops were the first preference regardless of age groups. The results indicate that the traditional stores co-exist with modern retail outlets such as hypermarket and supermarkets. In recent years, there has been a rather rapid penetration of hypermarkets in major towns in Malaysia. Currently, there are 50 hypermarkets, 66 superstores and more than 108 supermarkets in Malaysia. Hypermarkets such as Tesco and Carrefour are popular outlets for grocery shopping in urban areas, where about 45.0 to 60.0 per cent of urban consumers use them as the main outlet for the majority of their packaged groceries (USDA GAIN Report, 2006). However, for fresh products, consumers continue to prefer the wet markets, indicating coexistence of modern international-style retail outlets with traditional markets for fresh food.

For health supplements, pharmacies were the obvious outlet preferred by older adults as indicated by 1,029 respondents $(75.9 \%)$ although Chinese medical halls were preferred by $27.1 \%$ of the respondents. This suggests that older adults in Malaysia are both knowledgeable and empowered as consumers insofar as they are aware that it is unwise to purchase health supplements from potentially unqualified distributors. The success of the positioning strategy by pharmacies has gained the trust of consumers as the outlet of preference for genuine medications and health supplements. On the other hand, Chinese medical halls, the traditional outlet for medicines, remained popular among some older adults especially in rural areas. Contrary to a popular belief that older adults depend substantially on traditional healers, the findings of this study indicated a relatively low incidence of usage of traditional medica- 
tions, cited by only 140 or about $10 \%$ of the respondents. This preference pattern is consistent across the age groups as well as between older males and females.

More than half of the older adults $(\mathrm{N}=734)$ shopped for apparel at clothing stores followed by departmental stores $(\mathrm{N}=403,29.7 \%)$ and hypermarkets $(\mathrm{N}=261,19.2 \%)$. The number of respondents who bought clothes from boutiques was very low $(\mathrm{N}=86,6.3 \%)$, consistent with the low preference for design and style among older people. Both male and female respondents had similar preference patterns in which clothing stores were preferred followed by departmental stores and hypermarkets. Similarly, the preference pattern is also consistent across the three age groups.

Coffee shops, hawker centres and restaurants were the most popular eating outlets among older consumers as indicated by $710(52.3 \%), 685$ $(50.5 \%)$ and $663(48.9 \%)$ respondents respectively, whereas fast food outlets had a low preference $(\mathrm{N}=122)$ although patronage of fast food outlets possibly indicated time spent with their young relatives and grandchildren. The inclusion of porridge in the menu of local McDonald's restaurants is designed to cater to the cultural tastes of both young and old. More males preferred coffee shops $(\mathrm{N}=447)$ followed by hawker centres $(\mathrm{N}=403)$ and restaurants $(\mathrm{N}=358)$ while females preferred restaurants $(\mathrm{N}=305)$, followed by coffee shops $(\mathrm{N}=282)$ and hawker centres $(\mathrm{N}=263)$. Among the age groups, the 55-64 age groups the number who preferred coffee shops $(\mathrm{N}=444)$, hawkers centres $(\mathrm{N}=435)$ and restaurant $(\mathrm{N}=$ 408) did not differ greatly as almost the same number of respondents indicated preference for these eating outlets. Similarly for the age groups of 65-74 and 75 and older, coffee shops, hawker centres and restaurants were the major preferred outlets.

\section{Reasons for Patronage Preference, Frequency and Timing of Purchase}

In order to gain insights into older adults' preferences for store types with respect to the four categories of products, respondents were asked to indicate the reasons for their preferences. The single most important factor for the patronage of groceries was the ease of locating merchandise 
International Journal of Ageing and Later Life

Table 3. Summary of reasons for patronage preference.

\begin{tabular}{|c|c|c|c|c|c|c|c|}
\hline \multirow[b]{2}{*}{ Type } & \multirow[b]{2}{*}{ Patronage Preference } & \multicolumn{2}{|c|}{ Gender } & \multicolumn{3}{|c|}{ Age Groups } & \multirow[b]{2}{*}{ Total $^{\circ}$} \\
\hline & & Male & Female & $\begin{array}{l}55-64 \\
\text { years }\end{array}$ & $\begin{array}{l}65-74 \\
\text { years }\end{array}$ & $\begin{array}{c}75 \\
\text { years \& } \\
\text { above }\end{array}$ & \\
\hline \multirow{5}{*}{ Groceries } & $\begin{array}{l}\text { Ease of locating } \\
\text { merchandise/items }\end{array}$ & 640 & 461 & 675 & 318 & 108 & 1101 \\
\hline & Reasonable price & 419 & 317 & 464 & 208 & 64 & 736 \\
\hline & Product variety & 394 & 271 & 416 & 195 & 54 & 665 \\
\hline & $\begin{array}{l}\text { Preference for bill- } \\
\text { ing/ payment } \\
\text { method }\end{array}$ & 147 & 78 & 145 & 63 & 17 & 225 \\
\hline & $\begin{array}{l}\text { Have fast check-out } \\
\text { registers }\end{array}$ & 165 & 97 & 175 & 67 & 20 & 262 \\
\hline \multirow{4}{*}{$\begin{array}{l}\text { Health } \\
\text { Supple- } \\
\text { ments }\end{array}$} & $\begin{array}{l}\text { Products suitable to } \\
\text { physically/ health } \\
\text { need }\end{array}$ & 438 & 315 & 459 & 226 & 68 & 753 \\
\hline & $\begin{array}{l}\text { Ease of locating } \\
\text { merchandise/items }\end{array}$ & 219 & 151 & 224 & 103 & 34 & 361 \\
\hline & Reasonable pricing & 168 & 126 & 179 & 91 & 24 & 294 \\
\hline & $\begin{array}{l}\text { Preference for bill- } \\
\text { ing/ payment } \\
\text { method }\end{array}$ & 71 & 32 & 69 & 26 & 8 & 103 \\
\hline \multirow{3}{*}{ Apparels } & Reasonable price & 261 & 195 & 276 & 129 & 51 & 456 \\
\hline & $\begin{array}{l}\text { Ease of locating } \\
\text { merchandise/items }\end{array}$ & 208 & 166 & 208 & 125 & 41 & 374 \\
\hline & Product variety & 194 & 134 & 201 & 95 & 32 & 328 \\
\hline \multirow{3}{*}{ Eat Out } & Reasonable pricing & 279 & 215 & 295 & 158 & 41 & 494 \\
\hline & $\begin{array}{l}\text { Comfortable place to } \\
\text { shop or socialize }\end{array}$ & 257 & 172 & 262 & 121 & 46 & 429 \\
\hline & Product Variety & 123 & 127 & 152 & 72 & 26 & 250 \\
\hline
\end{tabular}

aMultiple responses permitted. 
$(\mathrm{N}=1,101)$ followed by reasonable price $(\mathrm{N}=736)$ and product variety $(\mathrm{N}=665)$ (Table 3). Both male and female respondents chose the same major reasons for their preferred stores. Across age groups, the same reasons motivated their preference for store types in the purchase of groceries.

For health supplements, products that suit health needs was the single most important factor reported by a total of $753(55.5 \%)$ respondents who favoured pharmacies as their preferred outlet. This was the same reason cited by males and females as well as all age groups. For apparels, reasonable pricing $(\mathrm{N}=456)$ was the most commonly cited reason that motivated them to patronize their preferred outlet. Ease of locating merchandise was the next reason quoted by $374(27.6 \%)$ respondents.

The research investigated frequency of purchase for the four product categories as this could be an important issue for older persons with regard to travel time, storage of goods, expenditure amounts and the like. Groceries were commonly bought on a daily or weekly basis whereas health supplements were purchased occasionally or on a monthly basis. A large number of older adults bought apparels occasionally. For patronage of eating outlets, a larger proportion of older adults ate out only occasionally compared to those who reported eating out on a weekly or daily basis.

To further understand the shopping behaviour of older adults, preferred time of purchase was examined and most preferred to shop in the mornings for grocery products and health supplements while apparels were bought at night and during weekends. The most popular meal for eating out was evening dinner. Grocery shopping was carried out by a larger proportion of older adults on weekdays rather than weekends. For health supplements, an almost equal number of respondents reported buying them on weekdays as on weekends.

In terms of time spent shopping for the four categories of products, most shopping excursions lasted between 1-2 hours. For the purchase of apparels and eating out, more of the respondents reported spending about 2-3 hours, longer than for other products. 


\section{Shopping Companions}

For grocery shopping and the purchase of health supplements, older adults usually went alone or with their spouse but hardly ever with friends. Apparels were bought in the company of family members, spouse and children. Older adults also tended to eat out with family members and with friends. This is a clear indication of the social circle of older adults and suggests an over-dependence on family members for all the categories of products except for eating out. More males shopped alone or with spouse but more females shopped with children or with friends. This could be due to the nature of purchases as females might have better product knowledge than males and hence males tend to depend more on their spouse when shopping for groceries. The same can be observed for health supplements in which men would shop with their spouse while women would shop with their children. More men would shop for apparels with a spouse or family members compared to women whereas more women preferred to shop with their children or friends. For eating out, it is again interesting to observe that more women ate out with children but more men ate out alone, with spouse, family members and friends.

Shopping companions to a certain extent reflect the information flow process. Therefore, it is interesting to note that the findings suggest a two-step communication process in which information is likely to flow from children to mothers and from then on to fathers. Alternative explanations could include the stereotyped roles of gender that are being practiced in most households of older adults in which females make decisions related to care of the family but are excluded from financial matters.

\section{How Products Are Obtained}

Visiting stores was the preferred method of product delivery for three of the four product categories included in this study. For eating out, of course, the older adults preferred to have their meals at the outlets, with a small number indicating the preference for take away. This is consistent with the earlier findings where eating out is more of a social activity that involves family members and friends. For health supplements, whilst 
there was a general preference to purchase products from outlets, more males preferred to visit the outlets compared to females while more females indicated the preference for door-to-door delivery suggesting that direct marketing appeals to women due perhaps to the convenience. The same patterns of preferences were observed for apparels.

\section{Consumer Problems}

To provide more depth to the understanding of older persons' consumer behaviour, the nature and extent of any problems or difficulties encountered was discussed since satisfaction with purchase also affects life satisfaction (Table 4). Respondents could provide answers from lists or openended suggestions.

The existence of long queues at check-out counters was the major complaint for groceries while high prices were cited as the major problem encountered by the older consumers for health supplements and apparels. Unclean premise was the major concern of these older people which was not surprising since they reported hawker centres and coffee shops as the place that they frequented. In addition, more men complained about an unattractive environment which again is consistent with the attitudes to eating outlets patronized by older adults. These concerns were consistent between older males and females as well as among the three age groups.

\section{Services Patronage Behavior}

Older consumers in Malaysia are clearly important customers for a number of types of services. Therefore, the reasons for the respondent's patronage and the motivations for their purchases were investigated for three main categories of services: transport, tourism and financial services.

\section{Mobility And Transport Services Used}

This study attempts to examine older adults' opinion about transportation as mobility is closely related to the availability of an efficient transportation system. Slightly more than $50 \%$ of respondents depended 
International Journal of Ageing and Later Life

Table 4. Summary of problems encountered when purchasing.

\begin{tabular}{|c|c|c|c|c|c|c|c|}
\hline \multirow[b]{2}{*}{ Type } & \multirow[b]{2}{*}{ Problems } & \multicolumn{2}{|c|}{ Gender } & \multicolumn{3}{|c|}{ Age Groups } & \multirow[b]{2}{*}{ Total $^{\mathrm{a}}$} \\
\hline & & Male & Female & $\begin{array}{l}55-64 \\
\text { years }\end{array}$ & $\begin{array}{l}65-74 \\
\text { years }\end{array}$ & $\begin{array}{c}75 \\
\text { years } \\
\& \\
\text { above }\end{array}$ & \\
\hline \multirow{4}{*}{ Groceries } & $\begin{array}{l}\text { Long queues at } \\
\text { check out counters }\end{array}$ & 342 & 246 & 396 & 148 & 44 & 588 \\
\hline & Prices too high & 257 & 189 & 290 & 106 & 50 & 446 \\
\hline & Unclean premises & 255 & 176 & 253 & 132 & 46 & 431 \\
\hline & $\begin{array}{l}\text { Assistance not } \\
\text { offered }\end{array}$ & 165 & 129 & 194 & 68 & 32 & 294 \\
\hline \multirow{3}{*}{$\begin{array}{l}\text { Health } \\
\text { Supplements }\end{array}$} & Prices too high & 200 & 167 & 218 & 118 & 31 & 367 \\
\hline & Unpleasant Staff & 157 & 117 & 159 & 84 & 31 & 274 \\
\hline & $\begin{array}{l}\text { Poor quality of } \\
\text { products }\end{array}$ & 105 & 58 & 90 & 55 & 18 & 163 \\
\hline \multirow{4}{*}{ Apparels } & Prices too high & 218 & 179 & 236 & 115 & 46 & 397 \\
\hline & $\begin{array}{l}\text { Long queues at } \\
\text { check out counters }\end{array}$ & 198 & 127 & 193 & 101 & 31 & 325 \\
\hline & Unpleasant staff & 178 & 140 & 186 & 105 & 27 & 318 \\
\hline & Lack of choice & 137 & 143 & 175 & 79 & 26 & 280 \\
\hline \multirow{4}{*}{ Eat Out } & Unclean premises & 527 & 414 & 599 & 292 & 95 & 986 \\
\hline & $\begin{array}{l}\text { Unhygienic prac- } \\
\text { tices }\end{array}$ & 526 & 371 & 559 & 252 & 86 & 897 \\
\hline & $\begin{array}{l}\text { Unattractive envi- } \\
\text { ronment }\end{array}$ & 180 & 105 & 189 & 73 & 23 & 285 \\
\hline & Prices too high & 87 & 91 & 101 & 60 & 17 & 178 \\
\hline
\end{tabular}

aMultiple responses permitted.

on buses for inter-city travel but they also relied on their own transport (38\% of the respondents). For urban travel, about $40 \%$ of respondents used buses and own transport to get to their destinations. Taxis were the other more frequently used mode of transport. 
To the older people, the single most important factor for transportation was reported to be the ease of use, followed by price and transport that did not prolong the journey. Overall, the major difficulty encountered by older adults with respect to public transportation was reliability which is mainly related to the punctuality of service. The other areas of concerns were safety and affordability. More males mentioned the importance of ease of use compared to females although there were no differences with respect to the types of problems encountered. Comparing the three age groups, more respondents in the younger age group noted safety as an important factor. The findings point to the relative seriousness of transport problems encountered by older adults as the views were consistent in terms of age and gender (Table 5).

Table 5. Transportation: Factors important in patronage behaviour and difficulties encountered.

\begin{tabular}{|c|c|c|c|c|c|c|c|}
\hline \multirow[b]{2}{*}{ Type } & \multirow[b]{2}{*}{ Items } & \multicolumn{2}{|c|}{ Gender } & \multicolumn{3}{|c|}{ Age Groups } & \multirow[b]{2}{*}{ Totala } \\
\hline & & Male & Female & $\begin{array}{l}55-64 \\
\text { years }\end{array}$ & $\begin{array}{l}65-74 \\
\text { years }\end{array}$ & $\begin{array}{c}75 \\
\text { years } \\
\& \\
\text { above }\end{array}$ & \\
\hline \multirow{4}{*}{ Factors } & Ease of use & 482 & 319 & 505 & 217 & 79 & 801 \\
\hline & Cheap & 342 & 225 & 354 & 159 & 54 & 567 \\
\hline & $\begin{array}{l}\text { Shorter } \\
\text { journey }\end{array}$ & 179 & 137 & 187 & 88 & 41 & 316 \\
\hline & Safety & 124 & 95 & 149 & 54 & 16 & 219 \\
\hline \multirow{4}{*}{ Difficulties } & Reliability & 256 & 168 & 254 & 130 & 40 & 424 \\
\hline & $\begin{array}{l}\text { Safety } \\
\text { concerns }\end{array}$ & 173 & 139 & 197 & 90 & 25 & 312 \\
\hline & Affordability & 187 & 124 & 189 & 91 & 31 & 311 \\
\hline & Availability & 120 & 120 & 135 & 71 & 34 & 240 \\
\hline
\end{tabular}

aMultiple responses permitted. 


\section{Patronage Behaviour in Tourism}

In terms of market segments, older adults in many developed countries are now regarded as a major target for tourism. Older adults are individuals who have the time and some also have the money to indulge in leisure activities (Chan et al. 2005; Horneman et al. 2002). This study therefore makes an initial attempt to ask what older Malaysians would like to patronize in tourism services. It briefly examines the destinations favoured by older adults and the factors that are important in purchase decisions as well as problems that they encountered. The main domestic destinations visited by older adults were big cities, followed by beaches, rustic villages and highland resorts. For foreign destinations, big cities emerged as the most visited places followed by religious places and historical sites. Island resorts and rustic villages were not high on the list of preferences (Table 6).

What motivated these older adults to choose their vacation packages was the question of interest. Cost was the most important factor cited by a large number of older adults followed by recommendations about the attractiveness of destinations, which suggest the importance of word of mouth communications or interpersonal sources. Concerns for distance and safety were the other two major reasons that explained their purchase behaviour. As older people may suffer from physiological degeneration, tiredness was the major problem encountered while travelling. Some mentioned that they faced problem with health and concerns for security as well as safety. These are common issues that have been found in other exploratory regional studies such as among Hong Kong older persons (Chan et al. 2005).

Factors important to older men and women were similar and problems encountered during vacations were common. This suggests no gender-specific factors or problems which could provide useful information for marketers interested in targeting older consumers. In terms of age groups, perhaps surprisingly, the younger age groups considered safety factors more than the older age groups. For problems encountered during vacation, the younger age groups again expressed more problems associated with health, security and safety worries (Table 7). 
Table 6. Holiday destinations.

\begin{tabular}{|c|c|c|c|c|c|c|c|}
\hline \multirow[b]{2}{*}{ Type } & \multirow{2}{*}{$\begin{array}{l}\text { Place of } \\
\text { Preference }\end{array}$} & \multicolumn{2}{|c|}{ Gender } & \multicolumn{3}{|c|}{ Age Groups } & \multirow[b]{2}{*}{ Total $^{\mathrm{a}}$} \\
\hline & & Male & Female & $\begin{array}{l}55-64 \\
\text { years }\end{array}$ & $\begin{array}{l}65-74 \\
\text { years }\end{array}$ & $\begin{array}{l}75 \text { years } \\
\& \text { above } \\
\end{array}$ & \\
\hline \multirow{5}{*}{ Domestic } & Big cities & 351 & 285 & 377 & 191 & 68 & 636 \\
\hline & Beaches & 326 & 264 & 369 & 167 & 54 & 590 \\
\hline & $\begin{array}{l}\text { Rustic } \\
\text { villages }\end{array}$ & 268 & 194 & 269 & 139 & 54 & 462 \\
\hline & $\begin{array}{l}\text { Highland } \\
\text { resorts }\end{array}$ & 214 & 158 & 242 & 99 & 31 & 372 \\
\hline & $\begin{array}{l}\text { Religious } \\
\text { places }\end{array}$ & 173 & 144 & 195 & 88 & 34 & 317 \\
\hline \multirow{5}{*}{ Foreign } & Big cities & 234 & 194 & 265 & 121 & 42 & 428 \\
\hline & $\begin{array}{l}\text { Religious } \\
\text { places }\end{array}$ & 198 & 139 & 190 & 109 & 38 & 337 \\
\hline & $\begin{array}{l}\text { Historical } \\
\text { sites }\end{array}$ & 102 & 91 & 118 & 55 & 20 & 193 \\
\hline & $\begin{array}{l}\text { Rustic } \\
\text { villages }\end{array}$ & 38 & 33 & 41 & 24 & 6 & 71 \\
\hline & $\begin{array}{l}\text { Island } \\
\text { resorts }\end{array}$ & 44 & 19 & 38 & 23 & 2 & 63 \\
\hline
\end{tabular}

aMultiple responses permitted

\section{Financial and Other Related Services}

This research provides an interesting and unusual insight into patronage of finance and financial-related services which are rarely covered in Asian studies of older persons. Of the total of 1,356 respondents, the majority $(n=1,104)$ had a savings account with a bank (Table 8$)$; this might be a high proportion for the age group in comparison with other parts of the region. A small percentage had fixed deposit account and a checking account but penetration rate of insurance was low as only 255 respondents reported having a life insurance policy. For health or medical insurance, the adoption rate was even lower since this insurance policy 
Table 7. Vacations: Factors important in patronage behaviour and difficulties encountered.

\begin{tabular}{|c|c|c|c|c|c|c|c|}
\hline \multirow[b]{2}{*}{ Type } & \multirow[b]{2}{*}{ Items } & \multicolumn{2}{|c|}{ Gender } & \multicolumn{3}{|c|}{ Age Groups } & \multirow[b]{2}{*}{ Total $^{\mathrm{a}}$} \\
\hline & & Male & Female & $\begin{array}{l}55-64 \\
\text { years }\end{array}$ & $\begin{array}{l}65-74 \\
\text { years }\end{array}$ & $\begin{array}{c}75 \\
\text { years \& } \\
\text { above }\end{array}$ & \\
\hline \multirow{4}{*}{ Factors } & Cost & 488 & 348 & 500 & 255 & 81 & 836 \\
\hline & Recommendations & 306 & 223 & 321 & 151 & 57 & 529 \\
\hline & Distance & 285 & 191 & 294 & 130 & 52 & 476 \\
\hline & Safety & 243 & 184 & 246 & 143 & 38 & 427 \\
\hline \multirow{3}{*}{ Difficulties } & $\begin{array}{l}\text { Tiredness from } \\
\text { long journey }\end{array}$ & 505 & 365 & 534 & 247 & 89 & 870 \\
\hline & Health problems & 185 & 181 & 197 & 127 & 42 & 366 \\
\hline & $\begin{array}{l}\text { Safety and secu- } \\
\text { rity worries }\end{array}$ & 170 & 110 & 166 & 94 & 20 & 280 \\
\hline
\end{tabular}

aMultiple responses permitted

has only gained prominence recently due to the escalating costs of medical care. Among the respondents, only 142 reported having owned a credit card indicating a low usage of credit facilities. However, it is interesting to note that a small number made use of will-writing services and portfolio management services to manage their wealth. Although the number of users was small, it nonetheless indicates the potential of such services as the future cohort of older adults in Malaysia will be better educated and financially more secure and knowledgeable. The demand for such services is expected to increase as those born between 1946 to 1964 move into the older age groups and with changes in the social environment where older adults increasingly will not depend on children as the principal financial safety net. In terms of gender differences in financial service usage, more males reported having life and medical insurance, property insurance, current accounts (checking accounts), owning credit cards and using will writing services. This is perhaps to be expected given the nature of most Asian societies in which males have 
Table 8. Use of banking/financial services.

\begin{tabular}{|c|c|c|c|c|c|c|}
\hline \multirow[b]{2}{*}{ Services } & \multicolumn{2}{|c|}{ Gender } & \multicolumn{3}{|c|}{ Age Groups } & \multirow[b]{2}{*}{ Totala $^{a}$} \\
\hline & Male & Female & $\begin{array}{l}55-64 \\
\text { years }\end{array}$ & $\begin{array}{l}65-74 \\
\text { years }\end{array}$ & $\begin{array}{l}75 \text { years } \\
\& \text { above }\end{array}$ & \\
\hline Savings account & 643 & 461 & 675 & 322 & 107 & 1104 \\
\hline Fixed deposits & 162 & 104 & 195 & 58 & 13 & 266 \\
\hline Life insurance & 171 & 84 & 193 & 51 & 11 & 255 \\
\hline Current account & 137 & 69 & 143 & 53 & 10 & 206 \\
\hline $\begin{array}{l}\text { Health/Medical } \\
\text { insurance }\end{array}$ & 104 & 57 & 128 & 27 & 6 & 161 \\
\hline $\begin{array}{l}\text { Property insur- } \\
\text { ance }\end{array}$ & 120 & 39 & 108 & 40 & 11 & 159 \\
\hline $\begin{array}{l}\text { Credit/charge } \\
\text { card }\end{array}$ & 97 & 45 & 124 & 15 & 3 & 142 \\
\hline $\begin{array}{l}\text { Will writing } \\
\text { service }\end{array}$ & 34 & 12 & 31 & 10 & 5 & 46 \\
\hline $\begin{array}{l}\text { Portfolio man- } \\
\text { agement }\end{array}$ & 27 & 14 & 28 & 12 & 1 & 41 \\
\hline
\end{tabular}

aultiple responses permitted.

generally been the major bread winners and with a concomitantly greater need for insurance protection than females, especially older women many of whom are not working for pay. As the husband is usually the main financial provider, they feel they have little need for such insurance and financial-related services. Comparing the age groups, it is again clear that the younger age group had significantly more financial services and insurance coverage than people in the older age groups. This would reflect the better income, education and knowledge of such services amongst the young-old group in particular.

Major factors important in purchase decisions for financial and related services were convenience and location especially for banking services, interest rates and, importantly, the availability of Islamic banking facilities that appeal to Muslims respondents. The principal problems reported by older adults when using such services included long queues 
and insufficient seating capacity. A small number complained about the unsatisfactory service provided by the service providers and the small print in many of the forms for transactions.

Analysed by gender, more males than females cited interest rates as an important factor and they also complained more about insufficient seating capacity. In terms of age, more of those in the younger age groups placed importance on convenience, location as well as interest rates while there was no difference with respect to the availability of Islamic banking facilities. With regard to problems encountered, more respondents in the younger-old age groups complained about long queues.

\section{Customer Satisfaction and Satisfaction with Life}

To provide a wider understanding of how older Malaysian consumers feel in terms of self-image or well-being, a final section enquired about life satisfaction although this was not a quality of life survey per se. One aim of this section was to assess the resilience and satisfaction with life of the respondents although this of course cannot be directly linked to the use of and attitudes to services in the absence of more detailed controls and research.

On the whole, the respondents representing Malaysian active older adults cannot be said to be very satisfied in terms of self report of life satisfaction. On a scale of 1 "strongly disagree" to 7 'strongly agree", the overall level of satisfaction among the older adults was at best moderate (mean $=4.95$, almost identical for males and females). A comparison of the age groups shows that no significant differences could be observed. Pearson's correlation shows that life satisfaction is positively correlated with satisfaction as consumers measured by the facilities within shopping outlets (at $r=0.185 p=.001$ ). This suggests that satisfaction as a consumer is related to life satisfaction as a whole.

Measured on a five-point Likert scale, the subjective assessment of older adults with respect to facilities within an outlet showed that they were most satisfied with customer service (mean=3.24, $\mathrm{SD}=1.12$ ), followed by the availability of rest areas (mean $=3.21, \mathrm{SD}=1.30$ ), elderly friendly products (mean=3.11, $\mathrm{SD}=1.17$ ), security (mean $=3.08, \mathrm{SD}=.23$ ) and checkout counters (mean=3.02, SD=1.21). They were not satisfied with stairs $($ mean $=2.66, \mathrm{SD}=1.27)$. Men were more concerned about security, regula- 
tions to protect older persons and stairs in which the mean scores were $3.16(\mathrm{SD}=1.24), 2.89(\mathrm{SD}=1.17)$ and $2.72(\mathrm{SD}=1.26)$ respectively compared to female respondents whose mean scores were $2.98 \quad(\mathrm{SD}=1.21), 2.76$ $(\mathrm{SD}=1.13), 2.58$ ( $\mathrm{SD}=1.28)$, respectively. No significant differences could be found by age groups with regard to all the factors measuring customer satisfaction that were included in this study.

\section{Conclusions: Impacts and Implications for Marketing to Older Persons}

This study in Malaysia, an ageing and industrializing country in Southeast Asia, is innovative in that it provides empirical information on older persons as consumers in a middle-income country as well as a conceptual context of active and successful ageing. All too often, there appears to be the stereotype of older persons as "invisible consumers", who are not taken into account when product ranges, choices and delivery are planned or when marketing is conducted. This is ironic in some ways, as the Asia-Pacific region was the first to develop a regional plan of action on ageing, promulgated in Macau in 1999 (ESCAP 1999). he inclusion of financial services and vacation choices takes the current study a stage further than any others and makes it yet more innovative. Such services are clearly relevant and of growing interest to older consumers in most Western societies, where indeed many financial and vacation services are specifically oriented to or designed for older people - but in a middleincome country this is highly unusual. Moreover, many reviews on older persons in this region and elsewhere have not been based on such systematically-gathered empirical evidence and have often implicitly, probably incorrectly, placed older consumers in a more dependent, less self-aware or less consumer-oriented category. This study provides empirical evidence to address the lack of information on older consumers in Malaysia.

Quite contrary to the common image of older persons as "invisible consumers", we found that older consumers in Malaysia are ready and able to voice their ideas and opinions. They have often formulated and thought through their needs and demands. They are in many ways "canny consumers" who know what they want and how to get it. Many 
respondents were clearly careful and thoughtful, maybe even demanding and could articulate their requirements. This is a strong image which fits in well with positive aspects of ageing in many current concepts, especially successful ageing, resilient ageing and active ageing concepts (Rowe \& Kahn 1997; WHO 2002; Scheidt et al. 1999; Gattuso 2003) - a positive image that is well worth noting for older consumers in other middleincome countries. In terms of WHO's active ageing policy framework (WHO 2002, p. 51-52), this study provides clear empirical evidence of issues related to participation of older persons from the consumer behaviour perspective.

Older Malaysian consumers in this study clearly seem to display many of the consumer traits that provide useful information to marketers as well as public policy makers in light of the recent increase in the price of petrol (by about 19\% compared to 2005). It is anticipated that this will cause an increase in the price levels of some goods and services. The findings show that older consumers tend to spend more on food compared to the national average of RM 426. They are generally price conscious especially for apparel and eating out but they are also concerned about suitability when it comes to the purchase of pharmaceutical products while ease of locating merchandise is paramount for groceries purchase. As consumers, they are confident and can articulate their needs and demands. However, they also voiced their concerns about the facilities within shopping areas that need to be improved to be more elderly friendly.

The findings of this study will be useful to marketers as an information step in understanding the factors underlying the purchase motivations of older consumers for four important product categories. The inclusion of services will also help marketers in identifying ways to improve service delivery quality and consumer satisfaction for this key category. We suggest the concept of quality of life and well-being should be extended beyond the usual health and related factors to encompass consumption-related activities which are part of the everyday life of older adults and form an integral part of the participation components of successful ageing. The approach of this research is in line with the lifecourse perspective which would see people of all ages as consumers and with rights and needs. Older consumers in this middle-income country 
do appear to be aware of their needs and can define what they see as deficiencies in services. This study will thus provide baseline information to help enable stronger niche marketing and consumer orientation to meet older persons' needs. It may even assist service providers in their strategic planning if the restructuring and reconfiguration of so many types of services proceed in Malaysia in the same directions as they have in most countries in the West.

However, the lack of a younger control group against which to compare the attitudes of older respondents might be seen as a limitation to this study. In the future, we propose to extend the research with controls or at least a comparison group from younger age ranges, so that we can make stronger statements about age-related profiles in consumer attitudes. In addition, it will be useful to marketers and public policy markers if research is conducted on the lifestyles of older consumers which should also focus on successful ageing and resilience in ageing amongst older consumers.

\section{References}

Andrews, G. J. \& Phillips, D. R. (eds.) (2005). Ageing and Place. London: Routledge.

Blaikie, A. (2005) Imagined landscapes of age and identity. In G. J. Andrews \& D. R. Phillips (eds.), Ageing and Place (pp. 164-175). London: Routledge.

Burt, S. \& Gabbott, M. (1995). The elderly consumers and non-food purchase behaviour. European Journal of Marketing 29(2): 43-57.

Chan, A. C. M., Phillips, D. R., Fong, F. M. S. \& Wong, E. H. Y. (2005). An exploratory study on the significance of outbound traveling for older persons in Hong Kong. Research Monograph Series, Asia-Pacific Institute of Ageing Studies, Lingnan University Hong Kong.

Chang, P. T. \& Tey, N. P. (2006). Empowering older adults as key resources in development in Malaysia. In H. Yoon and H. Jon (eds.) Handbook of Asian Aging (pp. 195-210). New York: Baywood.

Department of Statistics. (2001). Population and Housing Census of Malaysia. Kuala Lumpur: Government of Malaysia. 
Dychtwald, M. (1997). Marketplace 2000: Riding the wave of population change. Journal of Consumer Marketing 14(4): 271-275.

ESCAP (UN Economic and Social Commission for Asia and the Pacific). (1999). Macau Plan of Action on Ageing for Asia and the Pacific. New York: United Nations.

ESCAP (UN Economic and Social Commission for Asia and the Pacific). (2001). Reducing Poverty and Promoting Social Protection. New York: United Nations. UNESCAP Social Policy Paper No. 5.

ESCAP (UN Economic and Social Commission for Asia and the Pacific). (2002a). National Policies and Programmes on Ageing in Asia and the Pacific: An Overview and Lessons Learned. New York: United Nations. UNESCAP Social Policy Paper No. 9.

ESCAP (UN Economic and Social Commission for Asia and the Pacific). (2002b). Access to Social Services by the Poor and Disadvantaged in Asia and the Pacific: Major Trends and Issues. New York: United Nations. UNESCAP Social Policy Paper No. 11.

ESCAP (UN Economic and Social Commission for Asia and the Pacific). (2006). Population Data Sheet, 2006. Bangkok: UNESCAP. http://www.unescap.org/esid/psis/population/database/data_she et/index.asp

Gattuso, S. (2003) Becoming a wise old woman: resilience and wellness in later life. Health Sociology Review 12(2): 171-177.

Gilleard, C. (1996) Consumption and identity in later life: towards a cultural gerontology. Ageing \& Society 16(4): 489-498.

Hooyman, N. R. \& Kiyak, H. A. (2005). Social Gerontology: A Multidisciplinary Perspective. (7th ed.). Boston: Pearson.

Horneman L., Carter R. W., Wei S. \& Ruys H. (2002). Profiling the senior traveler: An australian perspective. Journal of Travel Research 41(1): 2337.

Kinsella, K. \& Phillips, D. R. (2005) Global aging: the challenge of success. Population Bulletin 60(1): 1-40.

Kontos, P. (2005). Multi-disciplinary configurations in gerontology. In G. J. Andrews \& D. R. Phillips (eds.), Ageing and Place (pp. 24-35). London: Routledge. 
Lumpkin, J. R., Greenberg, B. A. \& Goldstucker, J. L. (1985). Marketplace needs of the elderly: determinant attributes and store choice. Journal of Retailing 61(2): 75-105.

Moschis, G. P., Curasi, C. \& Bellenger, D. (2004). Patronage motives of mature consumers in the selection of food and grocery stores. The Journal of Consumer Marketing 21(2/3): 123-133.

Ng, A. C. Y., Phillips, D. R. \& Lee, W. K. M. (2002). Persistence and challenges to filial piety and informal support of older persons in a modern Chinese society: A case study in Tuen Mun, Hong Kong. Journal of Aging Studies 16: 1-20.

Novak, M. (2006). Issues in Aging. Boston: Pearson.

Ong, F. S. (2002). Ageing in Malaysia: A review of national policies and programmes. In D. R. Phillips \& A. C. M. Chan (eds.), Ageing and Long-Term Care: National Policies in the Asia-Pacific. (pp. 107-149). Singapore: Institute of Southeast-Asian Studies and Ottawa: IDRC.

Pala, J. (2005). Population Ageing Trends in Malaysia, Monograph Series No. 1. Population and Housing Census of Malaysia, 2000, Putrajaya, Malaysia: Department of Statistics.

Phillips, D. R. (ed.) (2000). Ageing in the Asian-Pacific Region. Routledge: London.

Phillips, D. R. \& Chan, A. C. M. (eds.) (2002). Ageing and Long-Term Care: National Policies in the Asia-Pacific. Singapore: Institute of SoutheastAsian Studies and Ottawa: IDRC.

Rowe, J. W. \& Kahn, R. L. (1997). Successful aging. The Gerontologist 37(4): 433-440.

Scheidt, R. J., Humpherys, D. R. \& Yorgason, J. B. (1999) Successful aging: what's not to like. Journal of Applied Gerontology 18(3): 277-282.

Silvers, C. (1997). Smashing old stereotype of 50-plus America. Journal of Consumer Marketing 14 (4): 303-309.

World Health Organization (WHO) (2002). Active ageing: A policy framework. Geneva: WHO. Available on http://www.who.int/ hpr/ageing/ (Accessed: January 15, 2006). 